\title{
大雪山国立会園，裾合平周辺における 登山道侵食の長期モニタリング
}

\section{渡辺悌二*・太田健- - **後藤 忠 志***}

要 旨 大雪山国立公園の中でももっとも利用者が多い地域の一つである，旭岳姿見の池から裾合平 周辺において，1991 年以降，10～13 年間にわたる登山道侵食のモニタリングを実施した。侵食 量・侵食速度の見積には，登山道の断面を反復測量する方法をとり，侵食量を体積ではなく流 失した土壤の面積であらわした。

算出された侵食速度は 193.4 1,402.5 $\mathrm{cm}^{2} / \mathrm{yr}$ (平均 $617.4 \mathrm{~cm}^{2} / \mathrm{yr}$ ) で, 観測地点による違いが 大きかった。また，土壤侵食量・侵食速度は，同一地点に扔いても年による変動が大きく，1３ 年間程度の短期間のモニタリングでは，侵食速度を正確に知ることはできない。短期間の侵食 速度は, たとえば 1999 年の事例からわかるように, 夏季の豪雨によって著しく大きくなる。こ れまで大雪山では, 融雪水の恒常的な供給が土壌侵食に大きな貢献をするものと考えられてき たが，夏季の豪雨の貢献も大きいと考えるべきであろう。

これらの結果から，中・長期的国立公園管理にとっては，長期モニタリングによる侵食速度 の見積が不可欠であることが強調される。しかし同時に, 短期間のデータの蓄積も必要であり, 定期的な反復測量を長期モニタリングの中に位置づける必要がある。

キーワード 大雪山国立公園，登山道侵食，長期モニタリング，反復測量，国立公園管理

\section{I. はじめに}

山岳国立公園をはじめとする日本の多くの高山地 域では，登山道侵食や植生破壞をはじめとする自然 環境の荒廃（小野ほか，1990；後藤・牧田，1990な ど)，ならびに自然体験の質の低下(愛甲ほか，1992； 愛甲・浅川，1996など）が問題視されるようになっ てきている。この中で，登山道荒廃に関しては，大 雪山国立公園において 1 年間の土壤侵食量を計測し た，Yoda (1991)，後藤 (1993)，沖（2001）の研究 があるが， 1 年間の観測に基づく侵食量・侵食速度 は，積雪量や雨量の年変動の影響を直接的に受ける ため，年による大きなばらつきをもつことが容易に 想像できる。
そこで，長期間の土壤侵食に関する研究が重要と なる。この種の研究としては，航空写真を用いて数 10 年オーダーで裸地化の進行を把握した例がある (小林, 1995; Watanabe and Ono, 1996)。また, 現 地に扔いては，山田（1993）や渡辺・深澤（1998）の ように，登山道開設当時あるいは登山道整備当時の 地表面が平坦であったと仮定して，調査時までの長 期間の侵食量・侵食速度を推定した例がある。さら に，実測結果に基づいて侵食量を見積もつた研究と しては, Yoda and Watanabe (2000)の7 年間の観 測例がある。

大雪山国立公園は，こうした登山道侵食に関する 研究がもつとも集中的に行われている地域の一つで ある。にもかかわらず，現在でも著しい登山道荒廃

* 北海道大学地球環境科学研究科 060-0810 札幌市北区北 10 西 5

** 北海道大学地球環境科学研究科 ・院 $060-0810$ 札幌市北区北 10 西 5

**** 秋田桂城短期大学地域社会学科 017-0046 大館市清水 2-3-4 
が進行しており，研究の継続ならびにその成果を実 際の公園管理にフィードバックしてゆく努力がさら に求められている。

そこで，本研究では，旭岳の北西に位置する，裙 合平周辺の登山道において, 1991 年以降, 10〜13 年 間の土壤侵食量・侵食速度の見積を行った。その上 で，侵食速度の決定要因について議論し，将来の山 岳国立公園の登山道管理に対する侵食速度の長期モ ニタリングの必要性を議論した。

\section{II. 調 查地 域}

調査は，旭岳ロープウェイの終着駅である姿見駅 から，裾合平および中岳温泉を経て，中岳分岐に至 るまでの登山道沿いを中心に実施した（第 1 図）。

旭岳ロープウエイは，旭岳温泉 $(1,100 \mathrm{~m})$ から姿 見駅 $(1,595 \mathrm{~m})$ 間で運行されており，かつては 46 人 乗りであったものが, 2000 年に 101 人乗りに大型化
され (渡辺・古畑，1998)，2002 年 6～10 月の期間に は 156,494 人がロープウェイで姿見の池遊歩道を訪 れている(土栄，2004）。姿見駅周辺は，大雪山国立 公園の中でも利用者がもっとも多い地域の一つであ る。

調査地域には，旭岳アメダス観測所 $(1,620 \mathrm{~m})$ が あり，夏季に降水量データが集められている。1990 〜2003 年のデー夕を整理したところ, 6 9 月の平均 降水量は704.4 mm（ただし，6月と9月には欠測日 が複数あり，実際の降水量はこの值よりもかなり多 いと考えられる）であった（第 1 表）。

\section{III. 調査方法}

標高 $1,305 \sim 2,070 \mathrm{~m}$ の 9 地点で(第 1 図), 登山道 を横切る両端（登山道脇の植生上）に，1991 年 7 月 11 日にアルミ製アングルを埋設した。このアルミ製 アングルを測量基準点として，登山道断面の表面形

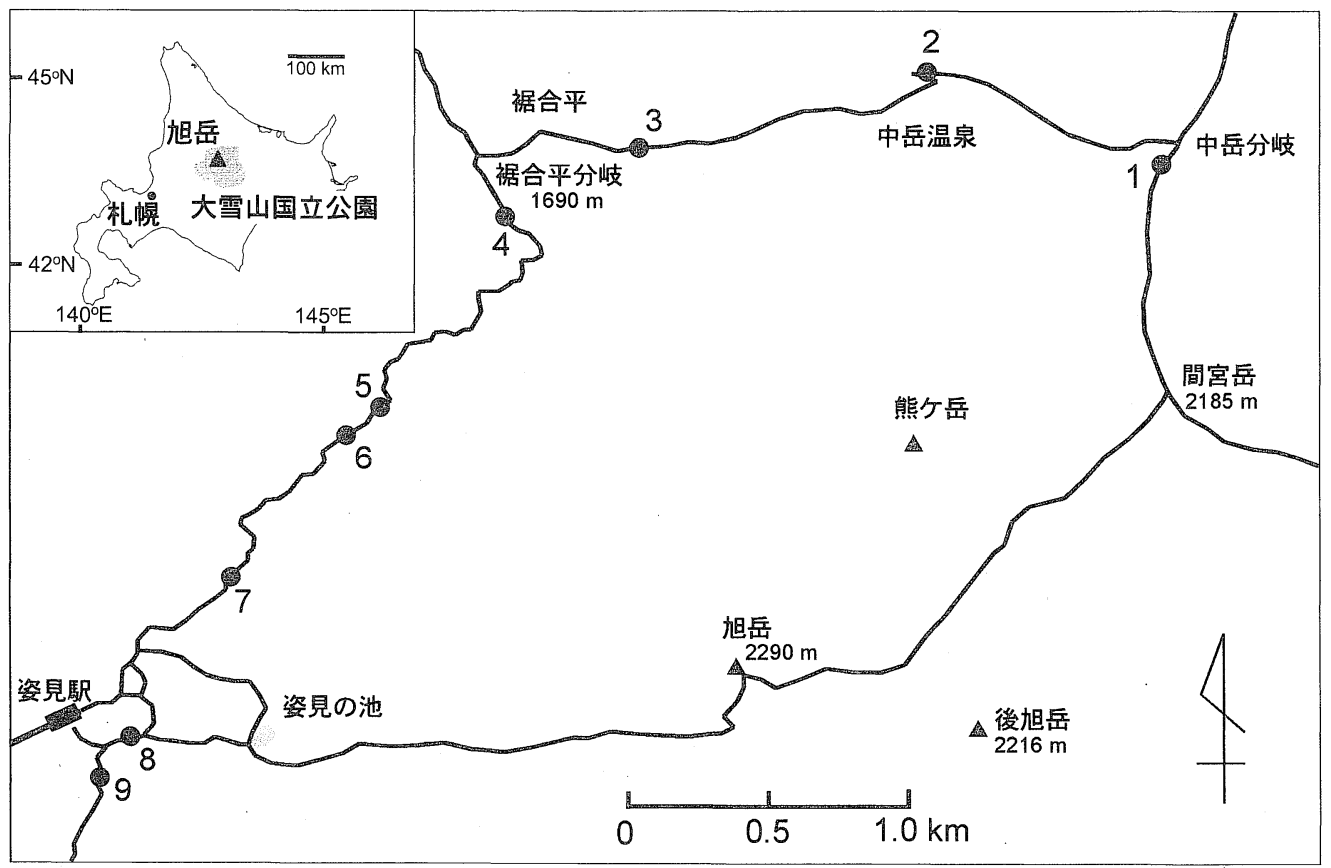

第 1 図 調查地域位置図 1-9 は調査地点。 
第 1 表 旭岳アメダス観測所 $(1,620 \mathrm{~m})$ における月降水量 $(\mathrm{mm})$

\begin{tabular}{r|rrrrrrrrrrrrrrr}
\hline \hline 月 & \multicolumn{10}{|c}{ 年 } \\
& 1990 & 1991 & 1992 & 1993 & 1994 & 1995 & 1996 & 1997 & 1998 & 1999 & 2000 & 2001 & 2002 & 2003 & 平均 \\
\hline 6 & & & & & & 41 & 18 & 16 & 39 & 425 & 32 & 76 & 65 & 71 & 87.0 \\
7 & 132 & & & 73 & & 377 & 345 & 182 & 193 & 294 & 455 & 620 & 327 & 80 & 279.8 \\
8 & 301 & 77 & 352 & 158 & 441 & 380 & 234 & & 337 & & 239 & 145 & 358 & 359 & 281.8 \\
9 & 199 & 148 & 328 & 156 & 239 & 150 & 202 & 111 & 314 & & 312 & 280 & 34 & 146 & 201.5 \\
\hline 合計 & 632 & 225 & 680 & 387 & 680 & 948 & 799 & 309 & 883 & 719 & 1,038 & 1,121 & 784 & 656 & 704.4 \\
\hline
\end{tabular}

第 2 表 侵食量および侵食速度の観測地点と測定日・測定日数

\begin{tabular}{|c|c|c|c|c|c|c|c|c|c|}
\hline $\begin{array}{l}\text { 地点 } \\
\text { 番号 }\end{array}$ & $\begin{array}{c}\text { 標高 } \\
(\mathrm{m})\end{array}$ & $\begin{array}{c}\text { 傾斜 } \\
\left(^{\circ}\right)\end{array}$ & $\begin{array}{l}\text { (A) } \\
\text { 基準点 } \\
\text { 設置日 }\end{array}$ & $\begin{array}{c}(\mathrm{B}) \\
\text { 第 } 1 \text { 回再測日 } \\
(\mathrm{A} \text { からのの日数 })\end{array}$ & $\begin{array}{c}(\mathrm{C}) \\
\text { 第 } 2 \text { 回再测日 } \\
(\mathrm{B} \text { 力 らの日数) }\end{array}$ & $\begin{array}{c}(\mathrm{D}) \\
\text { 第 } 3 \text { 回再測日 } \\
(\mathrm{C} \text { 加らの日数 })\end{array}$ & $\begin{array}{c}(\mathrm{E}) \\
\text { 第 } 4 \text { 回再測日 } \\
\text { (D からの日数) }\end{array}$ & $\begin{array}{c}(\mathrm{F}) \\
\text { 第 } 5 \text { 回再測日 } \\
(\mathrm{E} \text { 力らの日数) }\end{array}$ & $\begin{array}{c}(\mathrm{G}) \\
\text { 第 } 6 \text { 回再測日 } \\
(\mathrm{A} \text { から最終再 } \\
\text { 測日までの日数) }\end{array}$ \\
\hline 1 & 2,070 & 11.0 & 1991.7 .11 & $\begin{array}{c}\text { 1992.7.22 } \\
\text { (377 日間) }\end{array}$ & $\mathrm{n} / \mathrm{a}$ & $\mathrm{n} / \mathrm{a}$ & $\mathrm{n} / \mathrm{a}$ & $n / a$ & 377 \\
\hline 2 & 1,880 & 9.0 & 1991.7.11 & $\begin{array}{c}1992.7 .22 \\
\text { (377 日間) }\end{array}$ & $\begin{array}{c}1998.9 .30 \\
(2,261 \text { 日間) }\end{array}$ & $\begin{array}{c}2001.9 .20 \\
(1,267 \text { 日間) }\end{array}$ & $\begin{array}{c}2003.9 .6 \\
\text { (746 日間) }\end{array}$ & $\begin{array}{c}2004.7 .27 \\
\text { (326日間) }\end{array}$ & 4,977 \\
\hline 3 & 1,743 & 13.0 & 1991.7.11 & $\begin{array}{c}1992.7 .22 \\
\text { (377 日間) }\end{array}$ & $\mathrm{n} / \mathrm{a}$ & $\mathrm{n} / \mathrm{a}$ & $\mathrm{n} / \mathrm{a}$ & $\mathrm{n} / \mathrm{a}$ & 377 \\
\hline 4 & 1,710 & 5.0 & 1991.7.11 & $\begin{array}{c}1992.7 .22 \\
\text { (377 日間) }\end{array}$ & $\begin{array}{c}1998.9 .30 \\
(2,261 \text { 日間) }\end{array}$ & $\begin{array}{c}2001.9 .20 \\
(1,267 \text { 日間) }\end{array}$ & $\mathrm{n} / \mathrm{a}$ & $\mathrm{n} / \mathrm{a}$ & 3,905 \\
\hline 5 & 1,725 & 6.0 & 1991.7 .11 & $\begin{array}{c}\text { 1992.7.22 } \\
\text { (377 日間) }\end{array}$ & $\mathrm{n} / \mathrm{a}$ & $\mathrm{n} / \mathrm{a}$ & $\mathrm{n} / \mathrm{a}$ & $11 / a$ & 377 \\
\hline 6 & 1,668 & 2.0 & 1991.7 .11 & $\begin{array}{c}1992.7 .22 \\
\text { (377 日間) }\end{array}$ & $\begin{array}{c}1998.9 .30 \\
(2,261 \text { 日間) }\end{array}$ & $\begin{array}{c}2001.9 .20 \\
(1,267 \text { 日間) }\end{array}$ & $\mathrm{n} / \mathrm{a}$ & $\mathrm{n} / \mathrm{a}$ & 4,183 \\
\hline 7 & 1,640 & 4.5 & 1991.7.11 & $\begin{array}{c}\text { 1992.7.22 } \\
\text { (377 日間) }\end{array}$ & $\begin{array}{c}2003.9 .6 \\
(4,274 \text { 日間) }\end{array}$ & $\begin{array}{c}2004.7 .27 \\
\text { (326 日間) }\end{array}$ & $\mathrm{n} / \mathrm{a}$ & $\mathrm{n} / \mathrm{a}$ & 4,977 \\
\hline 8 & 1,615 & 4.0 & 1991.7 .11 & $\begin{array}{c}1992.7 .22 \\
\text { (377 日間) }\end{array}$ & $\mathrm{n} / \mathrm{a}$ & $\mathrm{n} / \mathrm{a}$ & $\mathrm{n} / \mathrm{a}$ & $\mathrm{n} / \mathrm{a}$ & 377 \\
\hline 9 & 1,305 & 10.0 & 1991.7.11 & $\begin{array}{c}\text { 1992.7.22 } \\
\text { (377 日間) }\end{array}$ & $\mathrm{n} / \mathrm{a}$ & $\mathrm{n} / \mathrm{a}$ & $\mathrm{n} / \mathrm{a}$ & $\mathrm{n} / \mathrm{a}$ & 377 \\
\hline
\end{tabular}

$\mathrm{n} / \mathrm{a}:$ データなし

態を不定期に反復測量することによって，土壌侵食 量・侵食速度を計算した。調査期間が 13 年と長かっ たため，設置した 9 地点のうち，2001～2004 年まで アルミ製アングルが動かずに残っていたのは，わず か 4 地点のみであった。

侵食量・侵食速度の計算にあたっては，従来から もつとも広く用いられている，登山道断面の面積変 化の実測に基づく手法(Cole, 1983)を用いた。これ は，侵食量を体積ではなく断面積で表現する簡便な 手法であるが, Jewell and Hammitt（2000)が再現 性と精度の点でもっとも高い評価を与えており，日 本でも従来のほとんどの研究でこの手法が採用され
ている (Yoda, 1991; 後藤, 1993; Yoda and Watanabe, 2000 など）。9 地点における登山道の表 面形態は，基準とした 1991 年 7 月 11 日から 1 年後 の 1992 年 7 月 22 日に再測した。また, 1998 年 9 月 30 日にはLoc. 2, 4, 6 に扔いて, 2001 年 9 月 20 日に はLoc. 2, 4 において, 2002 年 6 月 25 日にはLoc. 6 において，再測した。さらに，2003 年および 2004 年 については, 市販のデジタルカメラ(ニコン COOLPIX5000）を使ってステレオ写真を撮影して, 3 次元写真計測ソフト (Kuraves Ver. 3) を用いて Loc. 2, 7 で断面図を作成した。9 地点での侵食量・侵 食速度の観測総日数は 377〜 4,977 日間 (1〜 13 年間) 
である (第 2 表)。

次に，現地測量によって作成した登山道断面図を 基図として,デジタルプラニメータ (牛方商会製, XPLAN360CII+）を用いて登山道の土壌侵食量（断 面積）を計算し，また 3 次元写真計測法を用いた年 に関しては 3 次元写真計測ソフトを用いて土壤侵食 量 (断面積) を計算した。ある期間の土塎侵食量は, 実際には，登山道断面上での侵食面積と堆積面積と の収支として表現される。ほとんどの場合には侵食 量が圧倒的に大きく, 堆積を伴わない場合も多いが, 堆積が認められる場合には，侵食面積から堆積面積 を引いた差を侵食量として算出した。なお, 3 次元写 真計測法を使えば，断面積ではなく体積で土畩侵食 量を算出することができるが，ここではCole (1983) の手法による結果と比較を行うため, 断面積 で結果を出すことにした。

\section{IV。結果}

まず，測量頻度がもつとも大きなLoc. 2（1,880 m）の登山道断面変化について述べる（第 2 図）。ほ かの地点と同様に，1991 年 7 月 11 日に基準となる 断面を測量したが，断面形からは，この時点ですで
に最大侵食深が約 $80 \mathrm{~cm}$ あり，侵食が相当進行して いたと考えてよい。1992 年 7 月 22 日の登山道の表 面形態は 1 年前の形態と類似しており，もっとも傾 斜が大きな側壁と人が踏みつけをする登山道の底面 の両方で侵食が認められる。この 377 日間の侵食量 は $392.9 \mathrm{~cm}^{2}$ であり, 年間の侵食速度は $380.4 \mathrm{~cm}^{2} / \mathrm{yr}$ と計算された (第 3 表)。

次の再測の時点 (1998 年 9 月 30 日) には, 登山道 表面の侵食が全体にわたって進行しており，特に傾 斜が大きな北側の側壁（B'）の基部がオーバーハン グするようになっていた(第 2 図)。オーバーハング は2001年まではさらに拡大したが，2003 年には消 滅している。この期間には, 登山道の両脇の壁で堆 積が生じている $\left(\right.$ 合計 $\left.1,058.7 \mathrm{~cm}^{2}\right)$ 。これは, 上面が 植生に覆われた土塊 $\left(\mathrm{B}^{\prime}\right)$ が 2001〜2003 年の間に斜 面下方に移動したために生じたものである。2004 年 には B" の側壁が侵食を受けて急傾斜になってい る。1992１998 年の侵食量・侵食速度は，それぞれ $3,791.1 \mathrm{~cm}^{2}, 612.0 \mathrm{~cm}^{2} / \mathrm{yr}$ で，1991～1992 年の 1 年 間の速度と比べると 1.6 倍に増大した（第 3 表）が， 次の 1998 2001 年の期間には $312.1 \mathrm{~cm}^{2} / \mathrm{yr}$ と小さ くなった。2001〜2003 年にかけては $837.2 \mathrm{~cm}^{2} / \mathrm{yr} と$

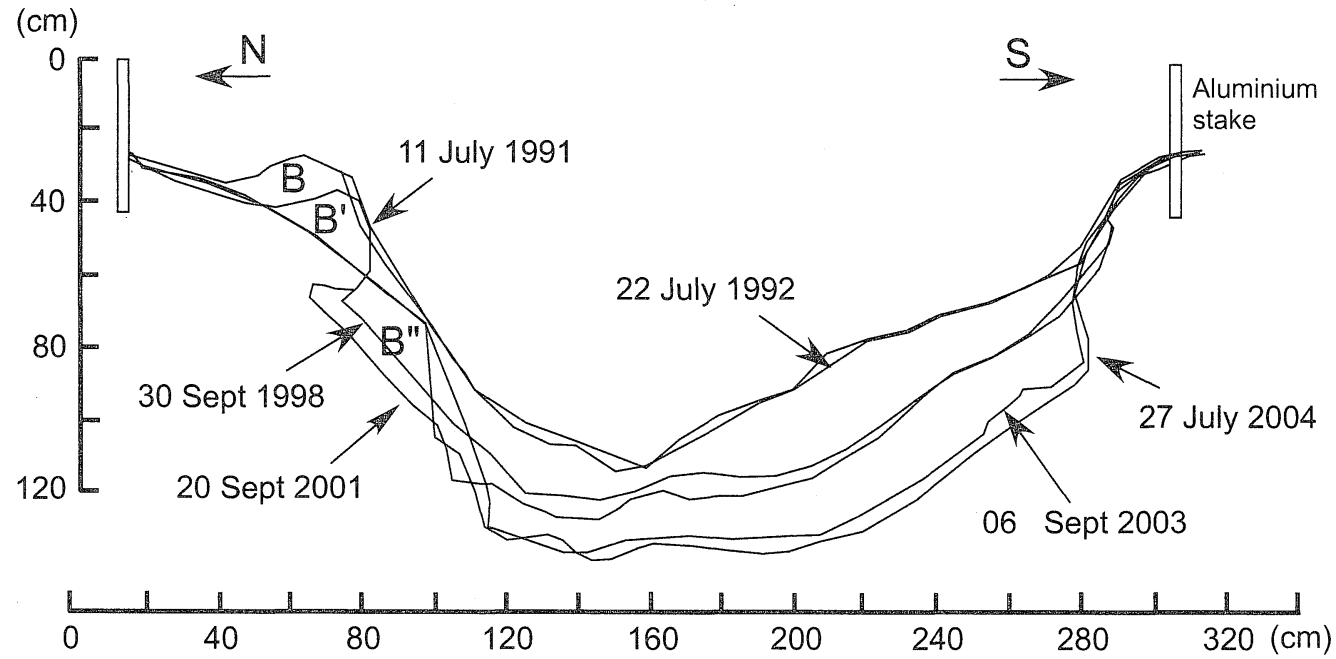

第 2 図 Loc. 2 (1,880 m) の登山道断面の変化 



C: Loc. 7

第 3 図 Loc. 4, Loc. 6, Loc. 7 の登山道断面の変化

第 3 表 大雪山，裾合平周辺の登山道侵食量・侵食速度

\begin{tabular}{|c|c|c|c|c|c|c|c|c|c|c|c|c|}
\hline \multirow{2}{*}{ 地点 } & \multicolumn{2}{|c|}{ 1991-1992 年 } & \multicolumn{2}{|c|}{ 1992-1998 年 } & \multicolumn{2}{|c|}{$\begin{array}{l}1998-2001 \\
\text { or } 2002 \text { 年 }\end{array}$} & \multicolumn{2}{|c|}{$\begin{array}{c}1992 \text { or } \\
2001-2003 \text { 年 }\end{array}$} & \multicolumn{2}{|c|}{ 2003-2004 年. } & \multicolumn{2}{|c|}{$\begin{array}{l}1991-2001 \text { or } \\
2002 \text { or } 2004\end{array}$} \\
\hline & $\begin{array}{l}\text { 侵食量 } \\
\left(\mathrm{cm}^{2}\right)\end{array}$ & $\begin{array}{l}\text { 侵食速度 } \\
\left(\mathrm{cm}^{2} / \mathrm{yr}\right)\end{array}$ & $\begin{array}{l}\text { 侵食量 } \\
\left(\mathrm{cm}^{2}\right)\end{array}$ & $\begin{array}{l}\text { 侵食速度 } \\
\left(\mathrm{cm}^{2} / \mathrm{yr}\right)\end{array}$ & $\begin{array}{l}\text { 侵食量 } \\
\left(\mathrm{cm}^{2}\right)\end{array}$ & $\begin{array}{l}\text { 侵食速度 } \\
\left(\mathrm{cm}^{2} / \mathrm{yr}\right)\end{array}$ & $\begin{array}{l}\text { 侵食量 } \\
\left(\mathrm{cm}^{2}\right)\end{array}$ & $\begin{array}{l}\text { 侵食速度 } \\
\left(\mathrm{cm}^{2} / \mathrm{yr}\right)\end{array}$ & $\begin{array}{l}\text { 侵食量* } \\
\left(\mathrm{cm}^{2}\right)\end{array}$ & $\begin{array}{l}\text { 侵食速度* } \\
\left(\mathrm{cm}^{2} / \mathrm{yr}\right)\end{array}$ & $\begin{array}{l}\text { 侵食量 } \\
\left(\mathrm{cm}^{2}\right)\end{array}$ & $\begin{array}{l}\text { 侵食速度 } \\
\left(\mathrm{cm}^{2} / \mathrm{yr}\right)\end{array}$ \\
\hline 1 & 438.2 & 424.3 & & & & & & & & & & \\
\hline 2 & 392.9 & 380.4 & $3,791.1$ & 612.0 & $1,083.2^{1)}$ & $312.1^{1)}$ & $1,711.1^{3)}$ & $837.2^{3)}$ & 290.7 & 325.5 & $7,269.0$ & 533.1 \\
\hline 3 & 343.6 & 3332.7 & & & & & & & & & & \\
\hline 4 & 794.6 & 769.3 & $7,640.3$ & $1,233.4$ & $6,570.0^{1)}$ & $1,892.7$ & & & & & $15,004.9$ & $1,402.5$ \\
\hline 5 & 315.9 & 305.8 & & & & & & & & & & \\
\hline 6 & 171.9 & 166.4 & $1,060.1$ & 171.1 & $984.6^{2)}$ & $232.6^{2)}$ & & & & & $2,216.6$ & 193.4 \\
\hline 7 & 290.0 & 280.8 & & & & & $4,263.7^{4)}$ & $8,364 \cdot 1^{4)}$ & 90.0 & 100.8 & $4,643.7$ & 340.6 \\
\hline 8 & 118.6 & 144.8 & & & & & & & & & & \\
\hline 9 & 240.6 & 232.9 & & & & & & & & & & \\
\hline 平均 & 345.1 & 334.2 & & & & & & & & & $7,283.6$ & 617.4 \\
\hline
\end{tabular}

*3 次元解析ソフトによる計算。その他は, 現地測量およびデジタルプラニメーターによる計算

${ }^{1)} 1998$-2001 年, ${ }^{2} 1998-2002$ 年, ${ }^{3)} 2001-2003$ 年, ${ }^{4)}$ 1992-2003 年 



第 4 図 4 地点における積算土培侵食量の変化

なり，2003〜2004 年には $325.5 \mathrm{~cm}^{2} / \mathrm{yr}$ とった。 1991 2004 年までの 13 年間の総侵食量は 7,269.0 $\mathrm{cm}^{2}$ で，年間侵食速度は $533.1 \mathrm{~cm}^{2} / \mathrm{yr}$ であった。

同様に 10 ～13 年間に方たって侵食量・侵食速度を 求めることができた地点は, Loc. 4, 6,7 のみで，そ れぞれの断面形態の変化注第 3 図 A-C に示してあ る。長期間の侵食速度を見積もることができた 4 地 点のうち，Loc. 4 において，すべての期間で最大の 侵食速度が求められた (第 3 表)。また逆に, 4 地点 の中ではLoc. 6 において, 侵食速度が最小となっ た。この結果，Loc. 4 では，10～11 年間の積算土壌 侵食量が Loc. 6 の 6 倍以上という大きな差となっ てあらわれた（第 4 図）。

\section{V. 考察}

\section{1. 大雪山国立公園における登山道侵食の特徵と 侵食速度の決定要因}

従来の多くの研究では，1年程度の観測期間の中 で, 土猿侵食の季節的な特徴, すなわち凍結融解期 には凍上によって登山道の両端の側壁で侵食が進行 し, 夏季には登山者の踏みつけによって登山道の底 面で侵食が進行すること(Yoda, 1991；後藤，1993） や，豪雨の影響で通常はほとんど侵食が生じない風 衝地でも著しい侵食が発生し得ること(沖，2001)な どが明らかにされてきた。

一方，登山道管理には将来の登山道侵食の予測が 必要であり，そのためには侵食速度の変化傾向を明 らかにすることが重要である。しかし，これまでの 研究では, 侵食速度が増加傾向にあるのか, あるい 
は一定速度を維持しているのか，といった議論は行 われてこなかった。大雪山国立公園内の黒岳石室周 辺の登山道で 7 年間の断面変化を扱った Yoda and Watanabe（2000）の研究においても, 反復測量によ るデー夕は示されておらず，侵食速度の変化につい ては議論が行われていない。本研究においても, 長 期モニタリングによるデータが少ないため議論は限 定されるが，以下では，長期モニタリングの結果を 短期間の結果と比べて，土壌侵食速度に関するこれ らの観測結果を将来の山岳国立公園管理に役立てる ための基礎としたい。

第 3 表にまとめた結果から,同一地点であっても, $1 \sim 3$ 年間といった短期間の侵食速度と $10 \sim 13$ 年間 の侵食速度とでは大きな差があることがわかる。ま た同一地点で, 短期間同士の侵食速度を比較すると, 年によるばらつきがきわめて大きいことがわかる (第 3 表，第 4 図)。すなわち，短期間のモニタリン グでは,代表的な侵食速度を得ることはできない。短 期間モニタリングの結果には, その期間の積雪量(融
雪水の供給量）と豪雨の有無など，さまざまな要因 が直接的に反映されるからである。

旭岳 $(1,620 \mathrm{~m})$ 抢よび層雲峡 $(540 \mathrm{~m})$ のアメダス 観測所における 1990〜2003 年の降水量デー夕をみ ると，1991〜1992 年には特異的な豪雨はなかったと いえる。すなわち, $334.2 \mathrm{~cm}^{2} / \mathrm{yr}$ という平均侵食速度 (第 3 表) は, 豪雨の影響を受けていない速度である。 一方, 1999 2001 年には豪雨が記録されている。旭 岳に挄いては，1999 年 6 月 23 日〜 7 月 3 日の 11 日 間の連続降雨は $524 \mathrm{~mm}$ に達しており（6月 29 日の 日降水量は $93 \mathrm{~mm}), 2000$ 年 7 月 13 ～20 日の 7 日間 の連続降雨は $237 \mathrm{~mm}$ （7 月 16 日の日降水量は 68 $\mathrm{mm}), 2001$ 年 7 月 3 9 日の 7 日間連続降雨は 234 $\mathrm{mm} ，$ 同年 7 月 19 26 日の 8 日間の連続降雨は 292 $\mathrm{mm}$ (7 月 23 日の日降水量は $186 \mathrm{~mm}$ ) であった。こ れは旭岳における $6,7,8$ 月の月平均降水量が 87.0 mm, 279.8 mm, 281.8 mm である (第1表)ことと 比べても大きな降雨であったといえる。さらに, 1999 年 $1 \sim 5$ 月には積雪が多く (第 5 図)，融雪水が多量

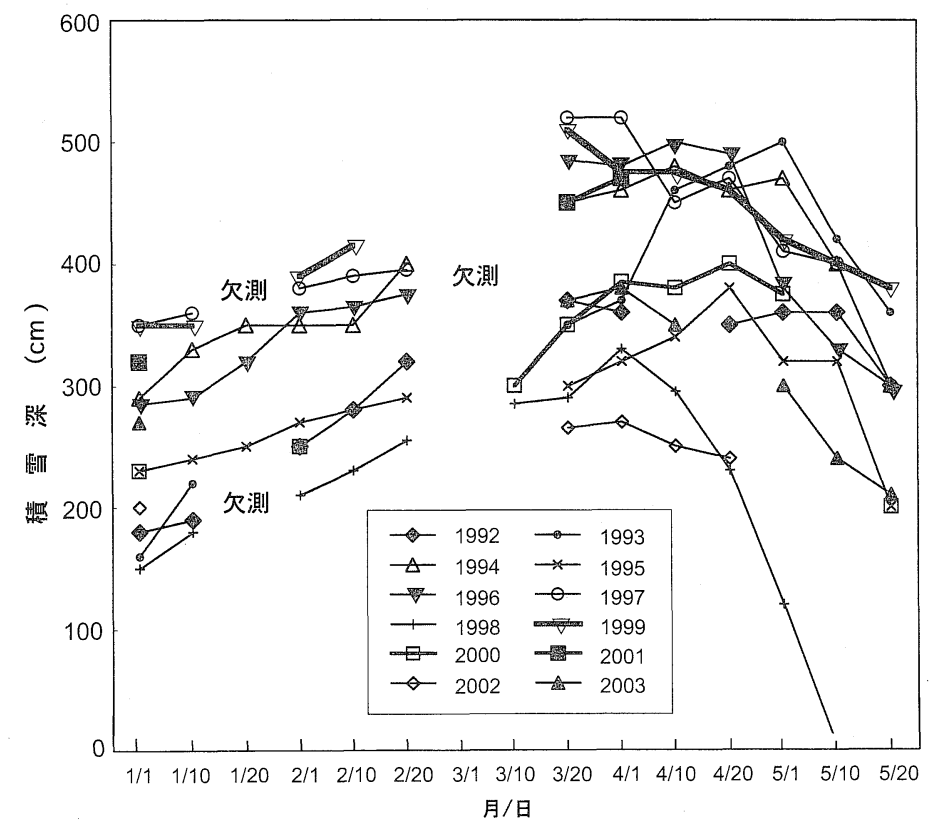

第 5 図 大雪山，黒岳七合目 $(1,510 \mathrm{~m})$ における積雪深の変化（データソース：りんゆう観光） 
に供給されていたと考えられる（2000 年の積雪量は 平均的で，2001 年の積雪量は欠測が多いがやや多 く，1999 年の融雪水の貢献が大きかった）。

こうした条件が整った結果，1998～2001 年の期間 には著しい侵食が生じたと考えられる。しかしなが ら，この期間には，現実には Loc. 2 や Loc. 7 の侵食 速度は大きな増加傾向にはなく, 著しい侵食が生じ たのはLoc. 4 のみであった(第 4 図)。Loc. 4 におい て著しい侵食があったのは, 植被土塊 V が流失した (第 3 図)ためである。こうした植被土塊が流失する には相当の流水が必要であり，1999 年から 2001 年 にかけて認められた豪雨と融雪水がその主な役割を 果たしているものと考えられる。

このように，流水に対する侵食の応答は，場所ご とに大きく異なる。Loc. 4 は, 登山道が拡幅する過 程にあった 1998～2001 年に豪雨の影響を受けたが， そのほかの登山道ではこの期間には大きな拡幅の過 程にはなく(第 3 図)，それぞれの登山道がおかれて いたこうした拡幅の段階の違いが，侵食速度の大小 につながったのであろう。

これまで，渡辺（2002）やWatanabe（2002）は， 大雪山の登山道に抢ける土袞侵食には融雪水の恒常 的な供給が決定的な役割を果たしていると考えてき た。すなわち, 本州太平洋側や西日本の山岳地域は 梅雨や台風の影響が大きい雨水侵食型の地域に，北 海道の山岳地域は融雪水の影響が大きい融雪水侵食 型の地域に大きく分けることができ，さらに本州日 本海側の山岳地域はこれら両者の影響を受けるだろ うと考えた。もちろん大雪山では，10〜13 年間と いつた長期間の土壤侵食には，基本的には融雪水の 貢献が大きいと考えて良いであろう。しかし，Loc. 4 でみられるような 1998 年以降の著しい土猿侵食 に関しては，融雪水に加えて夏季の大量の雨水が登 山道表面を流れたことも直接的な原因と考えられ， 北海道の山岳地域においても, 豪雨の影響はかなり 大きいと考えるべきであろう。

\section{2。 山岳国立公園管理への貢献}

以上の議論から，中・長期的国立公園管理にとっ ては，長期モニタリングによって侵食速度の傾向を 理解することが不可欠であるといえる。しかし，通 常の維持管理や緊急性を要する修復対応地点を明ら かにするなどの短期的国立公園管理には，短期デー 夕とその蓄積が必要である。さらに，中・長期的国 立公園管理にも短期のデー夕の蓄積が必要である。 たとえば，豪雨後には，通常は認められない規模の 侵食（沖，2001）や崩壞が大雪山国立公園内のあち こちで発生している。旭岳では 1997 年以降に降水量 が大きくなる傾向がある（第 4 図）が，最近の豪雨 による著しい登山道侵食は, 通常の登山道の維持管 理計画（すなわち，地種区分を基礎とし，自然環境 への人為的影響の程度や利用体験の質などを考慮し た管理計画) とは別に考える必要がある。今後は，数 10 年に一度, あるいは 100 年に一度の豪雨によって 破壞され得る登山道の整備をどのように考えるの か,という問題にも取り組んでゆかねばならない。こ のため, 1 年限りといった観測ではなく, 短期間の反 復測量を長期モニタリングの中に位置づける必要が ある。

さらに，黒岳石室周辺の登山道では，土留め階段 設置直後の 1999 2000 年までの断面測量結果から, 土留め階段による土壤の捕捉が土壤侵食と同時に生 じていることが認められており (沖，2001)，登山道 の断面形の反復測量は, 土留め階段をはじめとする 登山道整備手法の評価に対しても役立つといえる。

\section{VI. まと め}

現地での長期モニタリングに基づいて登山道の土 畩侵食速度を見積もった研究には, Cole（1991）の 11 年間の研究や, Yoda and Watanabe (2000)の 7 年間の研究があるにすぎない。本研究で示した 10 〜13 年間の結果は, 地点数はきわめて限られている が，世界でも最長期間のモニタリングに基づいてい 
る。

土壤侵食量・侵食速度は, 観測地点による違いが 大きく，たとえばLoc. 4 では 10〜11 年間の積算土 壤侵食量が Loc. 6 の 6 倍以上になった。4 地点にお ける $10 \sim 13$ 年間の土壌侵食速度は，193.4〜 1,402.5 $\mathrm{cm}^{2} / \mathrm{yr}$ (平均 $617.4 \mathrm{~cm}^{2} / \mathrm{yr}$ ) であった。また，土㗒 侵食量・侵食速度は，同一地点においても年による 変動が大きく, 1 3 年間程度の短期間のモニタリン グでは，侵食速度を正確に知ることはできない。短 期間の侵食速度は，1999 年のように, 夏季の豪雨に よって著しく大きくなる。これまで大雪山では融雪 水の恒常的な供給が土壤侵食に大きな貢献をするも のと考えられてきたが，夏季の豪雨の貢献も大きい と考光るべきであろう。

これらの結果から，中・長期的国立公園管理には， 長期モニタリングによって侵食速度を把握すること が不可欠であることが強調できる。しかし同時に, 短 期間のデー夕の蓄積も必要であり，定期的な反復測 量を長期モニタリングの中に位置づける必要があ る。

環境省は，国立公園の登山道の維持管理を環境省 単独で行ってゆくのではなく，地元の NGO など民 間人の手を借りながら進めてゆこうとしている。こ の際，登山道をレベル分けして異なる管理水準を適 用する検討が行われている（環境省・自然環境研究 センター，2002）。大雪山国立公園では，登山道の維 持管理が，すでに地元のボランティアの人たちの手 によって進められている（渡辺，2002，2003）が，こ うした動きは，全国の山岳国立公園に波及されてゆ くものと予想される。その際は，登山道侵食に関す るデータベース化が重要となり，長期モニタリング が容易にできるようなシステム作りが求められるで あろう。本研究で示した 2003 年および 2004 年の侵 食モニタリング手法は，市販のデジタルカメラで撮 影できる点ですぐれており，もしも行政やNGO ら による解析が不可能であったとしても，ステレオ写
真を定期的に撮影さえしておけげ，必要に応じて研 究機関などが解析を行うことも考えられる。

また，大雪山国立公園の黒岳石室周辺に押けるボ ランティアによる登山道の維持管理は，確実に土壌 侵食の軽減につながっている。こうした維持管理作 業の効果の評価の際にも, 断面モニタリングによっ て, 土袞侵食・堆積の収支を明らかにしてゆく必要 がある（渡辺，2004）。

\section{謝辞}

この調査結果は，環境省の登山道に関する委員会のた めの調査と平行してまとめたもので，サポートをしてい ただいた，環境省西北海道地区事務所の上原裕雄・元所 長，鍛冶哲郎・前所長ならびに青山銀三・現所長，出江俊 夫・前次長ならびに河本晃利・現次長, 中山隆治・前課長 ならびに奥山正樹・現課長, 上川自然保護管理事務所の三 島光博統括管理官をはじめとする環境省のみなさん，山 口和男さん (自然環境コンサルタント), 二橋愛次郎さん (北電総合設計株式会社), 浅川昭一郎教授 (北海道大学農 学部), その他多くの委員会関係者に感謝いたします。ま た, 黒岳七合目の積雪深データは,りんゆう観光株式会社 からのご好意で使用させていただくことができました。 お礼申しあげます。

(2005 年 1 月 6 日 受理)

\section{文献}

愛甲哲也・浅川昭一郎（1996）：山岳地に抢ける自然 探勝路の利用者行動モデルによる混雑度の解析. ランドスケープ研究，59-5，169-172.

愛甲哲也・浅川昭一郎・小林昭裕（1992）：大雪山国 立公園における登山道利用者の混雑感に関する 研究。造園雑誌, 55-5, 223-228.

沖 慶子 (2001): 大雪山国立公園, 黒岳石室周辺に おける登山道の保全のための研究。2000 年度北 海道大学大学院修士論文, $38 \mathrm{p}$. 小野有五・依田明実・後藤忠志 (1990)：登山道の侵 食について。森林航測，161，15-19.

環境省・自然環境研究センター (2002): 平成 13 年度 国立公園・国定公園にお注る登山道のあり方検 討調查報告書. $108 \mathrm{p}$.

後藤忠志 $(1993)$ ：大雪山・北八甲田山に扔ける登山 道の侵食。1992 年度北海道大学大学院修士論文, $41 \mathrm{p}$. 
渡辺悌二・太田健一・後藤忠志: 大雪山に扔ける登山道侵食の長期モニタリング

後藤忠志・牧田肇（1990）：北八甲田山地の自然破偯 と登山道。特定研究「北八甲田山地の自然と開 発」, 弘前大学, 89-141.

小林昭裕（1995）：斜面上に分散した登山道が形成 される要因。環境情報科学論文集，8，51-56。

土栄拓真 (2004)：大雪山国立公園・表大雪山域にお けるツアー登山の実態と利用者管理の方向性。 2003 年度北海道大学大学院修士論文, $37 \mathrm{p}$.

山田 周二 (1993)：白山に打ける登山道のひろが りとその速さ。筑波大学水理実験センター報告, 17 号, 65-72.

渡辺悌二 (2002) : 荒廃が進む登山道一これからの あり方，作り方。モーリー，7号，68-71.

渡辺悌二 (2003) :日本の山岳国立公園に打けるツ一 リズムと自然環境保全：ヒマラヤから学ぶこ と. 地理科学, 58, 146-156.

渡辺悌二 (2004)：山岳地生態系の脆弱性と地生態 学研究の現状・課題. 地学雑誌, 113, 180-190.

渡辺悌二・深澤京子（1998）：大雪山国立公園，黒岳 七合目から山頂間における過去 7 年間の登山道 の荒廃とその軽減のための対策. 地理学評論, 71A, 753-764

渡辺悌二・古畑亜紀（1998）：大雪山国立公園，旭岳 ロープウェイと姿見の池遊歩道の利用環境の改 善の方向性。北海道地理, 72, 1-9.

Cole, D.N. (1983) : Assessing and monitoring backcountry trail conditions. USDA Forest Service Research Paper INT-303, 10 p.

Cole, D. (1991): Changes on trails in the Selway-Bitterroot Wilderness, Montana, 1978-1989. USDA Forest Service Research Paper INT-450.
Jewell, M.C. and W.E. Hammitt (2000) : Assessing soil erosion on trails: A comparison of techniques. Cole, D.N. and McCool, S.F. eds.: Wilderness Science in a Time of Change. Vol. 5, U.S. Department of Agriculture, Forest Service, Rocky Mountain Research Station, Ogden, 133-140.

Watanabe, T. (2002) : Deterioration of mountain trails and their management in mountains of Japan. Proceedings of the International Seminar on the Utilization and Conservation of Mountains, Seoul, 34-38.

Watanabe, T. and Y. Ono (1996): Human impact on the high mountains of Japan. M.M. Ralston, K.F.D. Hughey, and K.F. O' Connor. eds. : Mountains of East Asia and the Pacific, Centre for Mountain Studies, Lincoln, 70-78.

Yoda, A. (1991): The erosion of mountain hiking trail near Mt. Kurodake hut in the Daisetsuzan Mountains National Park, central Hokkaido, Japan. MA Thesis, Hokkaido University, 29p.

Yoda, A. and T. Watanabe (2000): Erosion of mountain hiking trail over a seven-year period in Daisetsuzan National Park, central Hokkaido, Japan. Cole, D.N. and McCool, S.F. eds. : Wilderness Science in a Time of Change. Vol. 5, U.S. Department of Agriculture, Forest Service, Rocky Mountain Research Station, Ogden, 172-178. 


\title{
Long-term Monitoring of Trail Erosion around the Susoaidaira Area, Daisetsuzan National Park, Northern Japan
}

\author{
Teiji WATANABE*, Kenichi OTA**, and Tadashi GOTOH***
}

The amount and rate of soil erosion on hiking trails were monitored around the Susoaidaira area, Daisetsuzan National Park, Hokkaido, which experiences one of the heaviest visitations in mountain national parks of Japan. Method of Cole (1983) was used to understand the changes of the trail surface. Only four sites among nine sites delivered the results for the 10- to 13-year period.

The rates of soil erosion varied from site to site : 193.4 to $1,402.5 \mathrm{~cm}^{2} / \mathrm{yr}$ for the period of 10 13 years. Also, the amount and rates varied from year to year even at the same site. These results suggest that short-term monitoring of 1-3 years cannot provide the accurate amount/rate of erosion. Erosion rate derived from short-term monitoring becomes larger when heavy rainstorm comes as the case in 1999. Continuous supply of meltwater of snow in late spring and summer contributes to soil erosion in Daisetsuzan National Park ; however, heavy rainfall should be a great contributor to the soil erosion as well.

It is emphasized that mid-term and long-term management of mountain national parks requires understanding of soil erosion derived from long-term monitoring. At the same time, repeat measurement at short intervals should be also placed in the long-term monitoring.

Key words : Daisetsuzan National Park, Trail erosion, Long-term monitoring, Repeat measurement, National park management

* Graduate School of Environmental Earth Science, Hokkaido University, Sapporo 060-0810, Japan

** Graduate Student, Graduate School of Environmental Earth Science, Hokkaido University, Sapporo 060-0810, Japan

*** Department of Social Science, Akita Keijo Junior College, Odate 017-0046, Japan 